\title{
Prevalence of dental erosion among 18-year-old adolescents in the borderland districts of Lviv (Ukraine) and Lublin (Poland)
}

\author{
Teresa Bachanek1, Barbara Hendzel', Ewa Wolańska', Volodymir Szybinsky², Roman Ogonovsky², \\ Volodymir Hrynovets ${ }^{3}$, Dariusz Samborski ${ }^{1}$, Marta Nakonieczna-Rudnicka', Renata Chałas ${ }^{1}$ \\ ${ }^{1}$ Department of Conservative Dentistry and Endodontics, Medical University of Lublin, Poland \\ ${ }^{2}$ Danylo Halytsky Lviv National Medical University, Lviv, Ukraine \\ ${ }^{3}$ Department of Therapeutic Dentistry, Danylo Halytsky Lviv National Medical University, Lviv, Ukraine
}

Bachanek T, Hendzel B, Wolańska E, Szybinsky V, Ogonovsky R, Hrynovets V, Samborski D, Nakonieczna-Rudnicka M, Chałas R. Prevalence of dental erosion among 18-year-old adolescents in the borderland districts of Lviv (Ukraine) and Lublin (Poland). Ann Agric Environ Med. 2018; 25(1): 66-70. doi: 10.5604/12321966.1228948

\section{Abstract}

Introduction and objective. Recent epidemiological studies have shown an association between dental erosion occurrence and changes in lifestyle and dietary habits in both developed and developing countries, and now affects different regions of the world. Furthermore, in current literature, studies have shown that the prevalence of erosive tooth wear has increased particularly among the younger population. The aim of the study was to assess the prevalence and severity of erosive tooth wear among 18-year-old adolescents in the districts of Lviv (Ukraine) and Lublin (Poland).

Materials and methods. College students ( 254 subjects) aged 18, living in the Lviv and Lublin districts were examined. Erosive lesions presented in the teeth were assessed on the basis of the BEWE (Basic Erosive Wear Examination) index. Results. Among the 137 patients living in the Lublin district, 70 were females and 67 were males, while in the Lviv district, 60 women and 57 men were examined. In both districts, the following numbers of rural patients were examined: 66 in Lublin district and 56 in Lviv district; for urban inhabitants, the numbers were 71 in Lublin and 61 in Lviv. Analysing the BEWE values, it was noted that higher BEWE values, and resulting from them significant differences were observed in both male and female groups living in Lublin, compared with Lviv inhabitants. Based on clinical examination and statistical analysis, the occurrence of lesions of an erosive character in at least one sextant were observed in 59.85\% of patients from Lublin district, and in $42.74 \%$ of patients from Lviv district.

Conclusions. On the basis of the conducted study in the Polish and Ukrainian groups of 18-year-old adolescents living on the borderland, it can be stated that dental erosion is a problem noticeable in both groups of cohorts, but with higher prevalence in the Lublin district.

\section{Key words}

erosive tooth wear, dental erosion, BEWE

\section{INTRODUCTION}

Dental erosion - Erosive Tooth Wear (ETW) - is a pathological process of the mineralized tissues of teeth in which chemical compounds of non-bacterial origin play the major role. Predisposing factors also include medical conditions such as asthma, eating disorders and esophageal reflux however. Acids derived from food are the most frequent causes of erosion. Energy and refreshing beverages containing citric, phosphoric, and carbonic acids, fizzy drinks or citrus juices, as well as fresh fruit and vegetables, are the major sources of extraneous acids $[1,2,3,4,5]$. In order to neutralize their harmful influence it is necessary to know not only their $\mathrm{pH}$ value or erosion potential, but also the frequency and the time they remain in the oral cavity, hence the time they are in contact with the tooth surface. Recent epidemiological studies have shown an association between dental erosion occurrence and changes in lifestyle and dietary habits in both developed and developing countries, and its occurrence now affects different regions of the world. Furthermore, in

Address for correspondence: Renata Chałas, Department of Conservative Dentistry and Endodontics, Medical University of Lublin, Karmelicka 7, 20-081 Lublin, Poland e-mail: renata.chalas@umlub.pl

Received: 15 January 2016; accepted: 8 November 2016; first published on December, 2016 current literature, studies have shown that the prevalence of erosive tooth wear has particularly increased among the younger population $[6,7,8,9,10,11,12]$. The frontier locations of both the Lviv and Lublin districts could suggest a similar occurrence of erosive tooth wear in the youth population. Nevertheless, different socio-demographic and culture determinants in both countries allow the supposition that some differences could exist between the inhabitants of this Polish-Ukrainian borderland. Therefore, the aim of the study was to assess the prevalence and severity of erosive tooth wear among 18-year-old adolescents from the Lviv and Lublin districts.

\section{MATERIALS AND METHOD}

College students (254 subjects) aged 18, living in the Lviv and Lublin districts were examined. The patients were randomly chosen from these big urban agglomerations (over 200,000 inhabitants) as well as from rural regions [13]. The research was performed by dentists using standardized clinical dental examination methods, and by criteria of assessing the condition of the oral cavity according to principles and WHO procedures $[14,15]$. The dentists who conducted the dental examination had previously taken part in training 
combined with the calibration process, and for each of them the error size was determined. The agreement coefficient kappa of clinical examination results, according to Cohen, was 0.97 . The credibility of ratings was verified by a secondary examination with a $10 \%$ random sample. The examination was carried out in the conditions of a dental surgery using onetime dental instruments and under artificial illumination.

Erosive lesions presented in the teeth were assessed on the basis of the BEWE (Basic Erosive Wear Examination) index $[16,17,18,19]$ which facilitates the easy classification of the lesions. Dentition was divided into sextants. Each tooth in a sextant was examined in view of the occurrence of erosive lesions, which were classified on a 4 -grade scale with respect to all tooth surfaces: code 0 - lack of erosion, code 1 - initial, minor loss of enamel structure, code 2 - a prominent loss of mineralized tissue involving less than $50 \%$ of tooth surface, code 3 - a lesion with loss of enamel of over $50 \%$ of tooth surface (often occurring with exposed dentine). The highest value was noted for each sextant. BEWE index was calculated as the highest values in each sextant which enabled the risk assessment for erosive factors: 0-2 lack of risk, 3-8 minor risk, 9-13 medium risk, over $>14-$ high risk $[20,21]$.

The collected data were inserted into anonymous protocols coded with the number of each examined patient and statistically analysed. Values of measurable parameters were presented with Median, Minimal (Min.) and Maximal (Max.) values and Standard Deviation (SD) and for immeasurable parameters with Number (N) and Percentage (\%). To compare the distribution of changes in the examined groups, $\mathrm{Chi}^{2}$ test was used. In order to examine differences in BEWE values between groups, U Mann-Whitney test was performed. The level of significance $\mathrm{p}<0.05$ indicating significant differences or dependencies was accepted. Database and statistic examination were performed using software Statistica 9.1 (StatSoft.Poland).

The following abbreviations were used in the study: PL Lublin district; UA - Lviv district.

\section{RESULTS}

Among the 137 patients living in the Lublin district, 51.09\% $(\mathrm{n}=70)$ were females and $48.91 \%(\mathrm{n}=67)$ were males. In Lviv district, 60 women (51.28\%) and 57 men (48.72\%) were examined. In both districts, the following numbers of rural patients were examined: 66 in Lublin district and 56 in Lviv district; for urban inhabitants the numbers were 71 in Lublin and 61 in Lviv. Research material specifications are presented in Table 1 .

Table 1. Number (N) and Percentage (\%) of examined patients from Lviv and Lublin districts according to gender and place of residence

\begin{tabular}{llcccc}
\hline & & \multicolumn{2}{c}{ Lviv district } & \multicolumn{2}{c}{ Lublin district } \\
\cline { 3 - 6 } & & $(\mathrm{N})$ & $(\%)$ & $(\mathrm{N})$ & $(\%)$ \\
\hline \multirow{2}{*}{ Gender } & Female & 60 & 51.28 & 70 & 51.09 \\
\cline { 2 - 6 } & Male & 57 & 48.72 & 67 & 48.91 \\
\hline \multirow{2}{*}{ Total } & & $\mathbf{1 1 7}$ & $\mathbf{1 0 0 . 0 0}$ & $\mathbf{1 3 7}$ & $\mathbf{1 0 0 . 0 0}$ \\
\hline \multirow{2}{*}{ Totace of residence } & Rural area & 56 & 47.86 & 66 & 48.18 \\
\cline { 2 - 6 } & Urban area & 61 & 52.14 & 71 & 51.82 \\
\hline
\end{tabular}

BEWE values for particular groups of people with respect to their place of living and gender are presented in Table 2. Significant differences in the median value of BEWE $(\mathrm{p}=0.001)$ between the patients in the Lublin and Lviv districts were observed. When analysing the BEWE values, it was noted that the highest value occurred in the Lublin female group and it was higher in the urban area. The lowest BEWE values were noted in Lviv district groups, but the differences in median value of BEWE of the examined rural and urban male or female patients were not significant. However, in Lublin district, these differences were significant $(\mathrm{p}=0.014)$ in females and in males, similar to the rural and urban inhabitants $(p=0.015)$. There were no significant differences concerning the place of living between males and females in Lviv district; however, in the female group from Lublin, the BEWE values were significantly higher $(p=0.049)$ than in the females from the rural areas. Differences close to significance were also observed in the male group living in the rural and urban part of Lublin district. Higher BEWE values, and resulting from them significant differences were observed in both the male and female groups living in the Lublin district, compared with patients in the Lviv district.

Table 2. BEWE values in particular groups of patients according to place of residence and gender

\begin{tabular}{|c|c|c|c|c|c|c|c|}
\hline & & & Median & Min. & Max. & SD & $P$ value \\
\hline \multicolumn{3}{|l|}{ Lviv district } & 0 & 0 & 4 & 0.97 & \multirow{2}{*}{$P=0.001$} \\
\hline \multicolumn{3}{|l|}{ Lublin district } & 1 & 0 & 6 & 1.31 & \\
\hline \multirow{4}{*}{ Lviv district } & \multicolumn{2}{|l|}{ Female } & 0 & 0 & 4 & 0.99 & \multirow{2}{*}{$P=0.748$} \\
\hline & \multicolumn{2}{|l|}{ Male } & 0 & 0 & 4 & 0.95 & \\
\hline & \multicolumn{2}{|c|}{ Rural area } & 0 & 0 & 4 & 1.13 & \multirow{2}{*}{$P=0.934$} \\
\hline & \multicolumn{2}{|c|}{ Urban area } & 0 & 0 & 3 & 0.80 & \\
\hline \multirow{4}{*}{ Lublin district } & \multicolumn{2}{|l|}{ Female } & 1 & 0 & 6 & 1.43 & \multirow{2}{*}{$P=0.014$} \\
\hline & \multicolumn{2}{|l|}{ Male } & 1 & 0 & 4 & 1.11 & \\
\hline & \multicolumn{2}{|c|}{ Rural area } & 1 & 0 & 4 & 1.16 & \multirow{2}{*}{$P=0.015$} \\
\hline & \multicolumn{2}{|c|}{ Urban area } & 2 & 0 & 6 & 1.39 & \\
\hline \multirow{4}{*}{ Lviv district } & \multirow{2}{*}{ Female } & Rural area & 0 & 0 & 4 & 1.03 & \multirow{2}{*}{$P=0.947$} \\
\hline & & Urban area & 0 & 0 & 3 & 0.97 & \\
\hline & \multirow{2}{*}{ Male } & Rural area & 0 & 0 & 4 & 1.24 & \multirow{2}{*}{$P=0.907$} \\
\hline & & Urban area & 0 & 0 & 2 & 0.57 & \\
\hline \multirow{4}{*}{ Lublin district } & \multirow{2}{*}{ Female } & Rural area & 1 & 0 & 4 & 1.23 & \multirow{2}{*}{$P=0.049$} \\
\hline & & Urban area & 2 & 0 & 6 & 1.55 & \\
\hline & \multirow{2}{*}{ Male } & Rural area & 0 & 0 & 4 & 1.03 & \multirow{2}{*}{$\mathrm{P}=0.065 \sim$} \\
\hline & & Urban area & 1 & 0 & 4 & 1.13 & \\
\hline \multirow{4}{*}{ Female } & \multirow{2}{*}{$\begin{array}{l}\text { Rural } \\
\text { area }\end{array}$} & UA & 0 & 0 & 4 & 1.03 & \multirow{2}{*}{$P=0.119$} \\
\hline & & $\mathrm{PL}$ & 1 & 0 & 4 & 1.23 & \\
\hline & \multirow{2}{*}{$\begin{array}{l}\text { Urban } \\
\text { area }\end{array}$} & UA & 0 & 0 & 3 & 0.97 & \multirow{2}{*}{$P=0.001$} \\
\hline & & PL & 2 & 0 & 6 & 1.55 & \\
\hline & Rural & UA & 0 & 0 & 4 & 1.24 & $D=10$ \\
\hline & area & PL & 0 & 0 & 4 & 1.03 & $r-1.000$ \\
\hline & Urban & UA & 0 & 0 & 2 & 0.57 & \\
\hline & area & $\mathrm{PL}$ & 1 & 0 & 4 & 1.13 & 02 \\
\hline
\end{tabular}

UA - Lviv district, PL - Lublin district

Based on clinical examination and statistical analysis, the occurrence of lesions of an erosive character in at least one sextant were observed in $59.85 \%$ of patients from Lublin 
district, and in $42.74 \%$ of patients from Lviv district. This difference was statistically significant. Analysis of the percentage distribution for the presence of erosion revealed statistically significant differences between the occurrence of lesions in both females (PL - 88.67\%, UA - 55.56\%; $\mathrm{p}=0.006)$ and in males (PL - 69.44\%, UA - 34.78\%; $\mathrm{p}=0.009)$. Percentage distribution of the occurrence of erosive lesions (evaluation $\geq 1$ ) or their lack (evaluation 0 ) in particular sextants are presented in Table 3 .

Among patients from the Lublin district, erosive lesions were most common in the VI sextant (27.74\%), II sextant (27.01\%) and IV sextant (22.63\%), compared with the VI sextant (8.55\%), 19.66\% (II sextant) and 16.24\% (IV sextant) in patients from Lviv district. The lesions observed were statistically significant for VI sextant $(\mathrm{p}<0.001)$ and also for III $(p=0.009)$ and V sextants $(p=0.026)$. There were no differences in the remaining sextants concerning the advancement of erosive lesions in patients with respect to their native country. Healthy, mineralized tooth tissues (lack of lesions of erosive character) were mostly observed in patients living in Lviv district in III (94.87\%) and VI (91.45\%) sextants, compared with the Lublin district where they were observed in I and V sextants (90.51\%, 85.40\%, respectively). Although the differences in percentage distribution in sextants I, II and IV were not statistically significant, they were visible in the remaining sextants. It is worth noting that in the female group the data concerning changes in sextant III (UA - 8.33\%, PL - 24.29\%; $\mathrm{p}=0.016)$ and in V sextant (UA -

Table 3. Percentage distribution of occurrence of erosive lesions in particular sextants

\begin{tabular}{|c|c|c|c|c|c|c|c|c|c|c|c|c|}
\hline & \multirow{2}{*}{ Sextant } & & \multirow{2}{*}{ UA } & \multirow{2}{*}{ PL } & \multicolumn{2}{|c|}{ Female } & \multicolumn{2}{|c|}{ Male } & \multicolumn{2}{|c|}{ Urban area } & \multicolumn{2}{|c|}{ Rural area } \\
\hline & & & & & $U A$ & $P L$ & $U A$ & $P L$ & $U A$ & $P L$ & $U A$ & $P L$ \\
\hline \multirow{5}{*}{1} & \multirow{2}{*}{0} & $\mathrm{~N}$ & 110 & 124 & 57 & 61 & 53 & 63 & 59 & 64 & 51 & 60 \\
\hline & & $\%$ & 94.02 & 90.51 & 95 & 87.14 & 92.98 & 94.03 & 96.72 & 90.14 & 91.07 & 90.91 \\
\hline & \multirow{2}{*}{$1-2$} & $\mathrm{~N}$ & 7 & 13 & 3 & 9 & 4 & 4 & 2 & 7 & 5 & 6 \\
\hline & & $\%$ & 5.98 & 9.49 & 5 & 12.86 & 7.02 & 5.97 & 3.28 & 9.86 & 8.93 & 9.09 \\
\hline & \multicolumn{2}{|c|}{$\mathrm{P}$} & \multicolumn{2}{|c|}{0.301} & \multicolumn{2}{|c|}{0.215} & \multicolumn{2}{|c|}{0.896} & \multicolumn{2}{|c|}{0.251} & \multicolumn{2}{|c|}{0.775} \\
\hline \multirow{5}{*}{ II } & . & $\mathrm{N}$ & 94 & 100 & 48 & 47 & 46 & 53 & 46 & 52 & 48 & 48 \\
\hline & 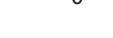 & $\%$ & 80.34 & 72.99 & 80 & 67.14 & 80.70 & 79.10 & 75.41 & 73.24 & 85.71 & 72.73 \\
\hline & & $\mathrm{N}$ & 23 & 37 & 12 & 23 & 11 & 14 & 15 & 19 & 8 & 18 \\
\hline & & $\%$ & 19.66 & 27.01 & 20 & 32.86 & 19.30 & 20.90 & 24.59 & 26.76 & 14.29 & 27.27 \\
\hline & & & & & & & & & & & & \\
\hline & & $\mathrm{N}$ & 111 & 116 & 55 & 53 & 56 & 63 & 58 & 59 & 53 & 57 \\
\hline & 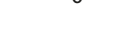 & $\%$ & 94.87 & 84.67 & 91.67 & 75.71 & 98.25 & 94.03 & 95.08 & 83.10 & 94.64 & 86.36 \\
\hline 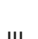 & 12 & $\mathrm{~N}$ & 6 & 21 & 5 & 17 & 1 & 4 & 3 & 12 & 3 & 9 \\
\hline & & $\%$ & 5.13 & 15.33 & 8.33 & 24.29 & 1.75 & 5.97 & 4.92 & 16.9 & 5.36 & 13.64 \\
\hline & & & & & & & & & & & & \\
\hline & & & & & & & & & & & & \\
\hline & 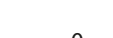 & $\mathrm{N}$ & 98 & 106 & 48 & 53 & 50 & 53 & 51 & 48 & 47 & 58 \\
\hline & & $\%$ & 83.76 & 77.37 & 80 & 75.71 & 87.72 & 79.10 & 83.61 & 67.61 & 83.93 & 87.88 \\
\hline 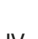 & 12 & $\mathrm{~N}$ & 19 & 31 & 12 & 17 & 7 & 14 & 10 & 23 & 9 & 8 \\
\hline IV & $1-2$ & $\%$ & 16.24 & 22.63 & 20 & 24.29 & 12.28 & 20.90 & 16.39 & 32.39 & 16.07 & 12.12 \\
\hline & & & & & & & & & & & & \\
\hline & 0 & $\mathrm{~N}$ & 110 & 117 & 58 & 58 & 52 & 59 & 58 & 58 & 52 & 59 \\
\hline & 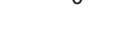 & $\%$ & 94.02 & 85.40 & 96.67 & 82.86 & 91.23 & 88.06 & 95.08 & 81.69 & 92.86 & 89.39 \\
\hline 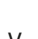 & 17 & $\mathrm{~N}$ & 7 & 20 & 2 & 12 & 5 & 8 & 3 & 13 & 4 & 7 \\
\hline & $1-2$ & $\%$ & 5.98 & 14.60 & 3.33 & 17.14 & 8.77 & 11.94 & 4.92 & 18.31 & 7.14 & 10.61 \\
\hline & & & & & & & & & & & & \\
\hline & & & & & & & & & & & & \\
\hline & . & $\mathrm{N}$ & 107 & 99 & 55 & 47 & 52 & 52 & 60 & 44 & 47 & 55 \\
\hline & 0 & $\%$ & 91.45 & 72.26 & 91.67 & 67.14 & 91.23 & 77.61 & 98.36 & 61.97 & 83.93 & 83.33 \\
\hline & & $\mathrm{N}$ & 10 & 38 & 5 & 23 & 5 & 15 & 1 & 27 & 9 & 11 \\
\hline & & $\%$ & 8.55 & 27.74 & 8.33 & 32.86 & 8.77 & 22.39 & 1.64 & 38.03 & 16.07 & 16.67 \\
\hline & & & & & & & & & & & & \\
\hline & & & & & & & & & & & & \\
\hline
\end{tabular}

Lack of erosive lesions - 0 , occurrence of erosive lesions $\geq 1$; UA - Lviv district, PL - Lublin district 
Table 4. Number $(\mathrm{N})$ and Percentage (\%) of patients with 0,1,2,3 BEWE codes according to gender and place of residence

\begin{tabular}{|c|c|c|c|c|c|c|c|c|c|}
\hline & \multicolumn{2}{|c|}{ Code 0} & \multicolumn{2}{|c|}{ Code 1} & \multicolumn{2}{|c|}{ Code 2} & \multicolumn{2}{|c|}{ Code 3} \\
\hline & & $(N)$ & (\%) & $(N)$ & (\%) & $(N)$ & (\%) & $(N)$ & (\%) \\
\hline \multirow{6}{*}{$\begin{array}{l}\text { Lviv } \\
\text { district }\end{array}$} & Female & 34 & 56.67 & 22 & 36.67 & 4 & 6.66 & 0 & 0 \\
\hline & Male & 37 & 64.91 & 16 & 28.07 & 4 & 7.02 & 0 & 0 \\
\hline & Total & 71 & 60.68 & 38 & 32.48 & 8 & 6.84 & 0 & 0 \\
\hline & Rural area & 34 & 60.71 & 17 & 30.37 & 5 & 8.92 & 0 & 0 \\
\hline & Urban area & 33 & 54.10 & 25 & 40.98 & 3 & 4.92 & 0 & 0 \\
\hline & Total & 67 & 57.27 & 42 & 35.89 & 8 & 6.84 & 0 & 0 \\
\hline \multirow{6}{*}{$\begin{array}{l}\text { Lublin } \\
\text { district }\end{array}$} & Female & 23 & 32.86 & 42 & 60.00 & 5 & 7.14 & 0 & 0 \\
\hline & Male & 32 & 47.76 & 32 & 47.76 & 3 & 4.48 & 0 & 0 \\
\hline & Total & 55 & 40.15 & 74 & 54.01 & 8 & 5.84 & 0 & 0 \\
\hline & Rural area & 31 & 46.97 & 32 & 48.48 & 3 & 4.55 & 0 & 0 \\
\hline & Urban area & 24 & 33.81 & 42 & 59.15 & 5 & 7.04 & 0 & 0 \\
\hline & Total & 55 & 40.15 & 74 & 54.01 & 8 & 5.84 & 0 & 0 \\
\hline
\end{tabular}

3.33\%, PL - 17.14\%; $\mathrm{p}=0.025)$ and in VI sextant $(\mathrm{UA}-8.33 \%$, $\mathrm{PL}-32.86 \%$; $\mathrm{p}=0.001)$ were statistically significant. In the male group from Lviv district, these differences were only observed in VI sextant (UA - 8.77\%, PL - 22.39\%; $\mathrm{p}=0.040$ ). Significant differences were only observed in the group of patients living in urban areas and concerned IV $(\mathrm{p}=0.034)$, $\mathrm{V}(\mathrm{p}=0.037)$ and $\mathrm{VI}(\mathrm{p}<0.001)$ sextants.

Table 4 presents the number and percentage of examined patients in whom the erosive lesions were classified by codes in compliance with BEWE index and according to the place of residence and gender. The research took into consideration the code defining the most advanced lesion on the tooth surface. In Lublin district, code 0 occurred in $40.15 \%$ of patients, code 1 in $54.01 \%$, code 2 in 5.84\%. In Lviv district, code 0 occurred in $57.27 \%$ of patients, code 1 in $35.89 \%$ and code 2 in $6.84 \%$. In the course of examination, no most advanced changes defined by code 3 were observed. The most severe erosive lesions, defined by code 2 , occurred in the male group $(7.02 \%)$ and in patients living in rural areas (8.92\%) in the Lviv district, and in the Lublin district in males (4.48\%) and in urban inhabitants (7.04\%).

\section{DISCUSSION}

This is the first study investigating the problem of erosive tooth wear among Polish and Ukrainian 18-year-old adolescents. Nevertheless, in the literature, there are numerous studies describing long-term observations concerning tooth erosion in many regions of the world [4, $5,6,7,8,9,10,11]$. The increasing frequency of erosion occurrence makes it necessary to introduce a uniform, standardised, international index suitable for evaluating teeth surfaces in both individual patients and the whole population $[22,23,24]$. For example, Norwegian researchers assessed erosive lesions on teeth surfaces using 2 indices: VEDE (Visual Erosion Dental Examination) and BEWE (Basic Erosive Wear Examination). The greatest convergence in observations (86\%) concerned codes 0 and 3 (convergence in $67 \%)$. Difficulties in assessment concerned initial erosive lesions (30\% convergence) and slightly advanced changes (57\% convergence) [25]. Similar observations can be found in the study by Dixon et al., in which the research was also conducted based on 2 indices: TWI (Tooth Wear Index) and BEWE. BEWE index proved to be decidedly more sensitive and specific [26]. Another study by Margaritis et al. presents 3 different indices used to assess erosive lesions: BEWE (Basic Erosive Wear Examination), S-TWI (Simplified Tooth Wear Index) and EV.I.D.E (Evaluating Index of Dental Erosion) [6]. However, the most popular and recently most recommended by European Federation for Conservative Dentistry is the BEWE index [27]. Research carried out among Greek adolescents aged 14-16 years showed that the BEWE index proved to be the most accurate in clinical evaluation among the used indices, and indicated the presence of erosive lesions in $58 \%$ of the examined patients [6]. Derry et al. noted the occurrence of erosive lesions in maxillary incisors in $41 \%$ of examined adolescents in the USA and $37 \%$ in the UK. In both countries, erosive lesions were revealed in $42.2 \%$ of females and $35.9 \%$ of males. However, these differences were not significant, and separately in the UK, erosive lesions were observed in $45.1 \%$ of males and $31.1 \%$ of females but in the USA amounted to $39.7 \%$ in males and $40.8 \%$ in females [7]. Long-term research by Dutch authors showed the occurrence of erosive lesions in $32.3 \%$ of 12 - 13-year-olds examined. It is worth emphasizing that a significant advancement of erosive lesions, from $1.8 \%$ - 13.3\%, was observed after 18 months of observations. There was a statistically significant difference in the number of erosive lesions between the group of girls and the group of boys [8]. Another study conducted by the same authors revealed erosive lesions in $30.4 \%$ of 11 -year-old children and in $44.2 \%$ of 15 -year-old adolescents. Advanced lesions involving the enamel and dentine were observed in $1.8 \%$ of 11 -year-olds, and in $23.8 \%$ of 15 -year-old adolescents [9]. Árnadóttir et al., who examined 15-year-olds from Iceland exposed to dietary factors causing erosion, reported the occurrence of erosion in $20 \%$ of those examined. Initial lesions involving only the enamel occurred in $21.6 \%$ of the examined, and the most advanced (involving enamel and dentine of a few teeth with a visible chamber of the tooth) in $5 \%$ of adolescents [10]. Holbrook et al., while assessing the condition of teeth tissue using the BEWE index, concluded that among $30.7 \%$ of the 15 -year-olds examined, erosive lesions occurred in $38.3 \%$ of boys and $22.7 \%$ of girls [28]. Bartlett et al. proved that the highest percentage of the examined had code $0-42.9 \%$, while for code $1-27.7 \%$, code $2-26.1 \%$, and code $3-3.3 \%$, according to the BEWE [29].

Research concerning the frequency of occurrence of erosive lesions among professional swimmers showed that both in the control group and in the examined group changes were observed in $17.56 \%$ of those examined $-10.15 \%$ in the control group and $25.80 \%$ in professional swimmers [30]. No differences were observed in the degrees of lesions advancement with respect to gender or to the examined group. Erosive lesions, regardless of location, were only observed in the enamel, and no severe erosive lesions with exposed dentine were observed in any of the patients. Research by Kaczmarek et al. showed that among subjects exposed to intrinsic and extrinsic acids, the most advanced erosive lesions occurred in sextants II and V [5]. However, the presented study revealed the most frequent occurrence of these changes in sextants VI and II in the Lublin district and in sextants II and IV in the Lviv district. The studies conducted among dentistry students by the Ukrainian researchers revealed the presence of dental erosive lesions in $4 \%$ of the patients [31], but the epidemiological study of Polish 
young adults revealed up to $42 \%$ with signs of dental erosions [32]. Due to scarcity of studies in which the BEWE index was used to assess dental erosion in borderland districts of Lublin and Lviv, and the lack of any detailed analysis of this problem, comparison with the presented study was difficult. However, the authors believe that the BEWE index allows diagnosing and determining the degree of advancement of erosive lesions in clinical practice, and the reliable comparison between cohorts of adolescents from neighbouring countries.

\section{CONCLUSIONS}

On the basis of the conducted study in Polish and Ukrainian groups of adolescents aged 18 years and living in the borderland, it can be stated that dental erosion is a problem noticeable in both groups of cohorts, but with higher prevalence in the Lublin district. The severity of erosive tooth wear was localized only to the enamel (BEWE 1 and 2), but persons without erosion (BEWE 0) in all sextants were more commonly found in the Lviv district.

\section{REFERENCES}

1. Scheutzel P. Etiology of dental erosion-intrinsic factors. Eur J Oral Sci. 1996; 104(2): 178-190.

2. Strużycka I, Rusyan E, Bogusławska-Kapała A. Tooth erosion - a multidisciplinary approach. Pol Merkur Lekarski. 2016; 40(236): 79-83.

3. Chomyszyn-Gajewska M. Current concepts on erosive tooth wear review of literature. J Stoma. 2007; 60(8): 519-526.

4. Aguiar YP, dos Santos FG, Moura EF, da Costa FC, Auad SM, de Paiva SM, Cavalcanti AL. Association between dental erosion and diet in Brazilian adolescents aged from 15 to 19: a populationbased study. ScientificWorldJournal. 2014 Feb 13; 2014:818167. doi: $10.1155 / 2014 / 818167$

5. Kaczmarek U, Sołtan E. Evaluation of dental erosions of extrinsic and intrinsic origin with use of BEWE index. Dent Med Probl. 2011; 48(1): 23-29.

6. Margaritis V, Mamai-Homata E, Koletsi-Kounari H, Polychronopoulou A. Evaluation of three different scoring systems for dental erosion: a comparative study in adolescents. J Dent. 2011; 39(1): 88-93.

7. Deery C, Wagner ML, Longbottom C, Simon R, Nugent ZJ. The prevalence of dental erosion in a United States and United Kingtom sample of adolescents. Pediatr Dent. 2000; 22(6): 505-510.

8. El Aidi H, Bronkhorst EM, Truin GJ. A longitudinal study of tooth erosion in adolescents. J Dent Res. 2008; 87: 731-735.

9. El Aidi H, Bronkhorst EM, Huysmans MCH, Truin GJ. Dynamics of tooth erosion in adolescents: A 3-year lingitudinal study. J Dent. 2010; 38(2): 131-137.

10. Árnadóttir IB, Sæmundsson SR, Holbrook WP. Dental erosion in Icelandic teenagers in relation to dietary and lifestyle factors. Acta Odontol Scand. 2003; 61(1): 25-28.

11. Al-Ashtal A, Johansson A, Omar R, Johansson AK. Dental erosion in groups of Yemeni children and adolescents and the modification of an erosion partial recording system. Int J Paediatr Dent. 2016 Aug 21. doi: 10.1111/ipd.12263.

12. Alaraudanjoki V, Laitala ML, Tjäderhane L, Pesonen P, Lussi A, Anttonen V. Association of erosive tooth wear and dental caries in Northern Finland Birth Cohort 1966 - an epidemiological crosssectional study. BMC Oral Health. 2016 Jul 4; 17(1):6. doi: 10.1186/ s12903-016-0232-x.

13. Runge A. Methodological problems associated with research midsize towns in Poland. Prace Geograficzne, Instytut Geografii i Gospodarki Przestrzennej UJ. 2012; 129: 83-101. doi: 10.4467/20833113PG.12.015.0523

14. Oral health surveys: basic methods - 5th edition, 2013.

15. Oral Status Euro (Tool for Collection of Data on Oral Health Status). WHO Geneva.1997.

16. Wang X, Lussi A. Assessment and management of dental erosion. Dent Clin North Am. 2010; 54(3): 565-578.

17. Bartlett D, Ganss C, Lussi AB. Basic Erosive Wear Examination (BEWE): a new scoring system for scientific and clinical needs. Clin Oral Investig. 2008; 12(Suppl. 1): S65-S68.

18. Olley RC, Wilson R, Bartlett D, Moazzez R. Validation of the Basic Erosive Wear Examination. Caries Res. 2014; 48(1): 51-56.

19. Bartlett D. A proposed system for screening tooth wear. Br Dent J. 2010; 208(5): 207-209.

20. Picos AM, Chisnoiu AM, Lasserre JF, Spinei A, Picos A. Dental erosion - literature update. HUM Bioflux. 2013; 5(3): 135-141.

21. Huysmans MC, Chew HP, Ellwood RP. Clinical studies of dental erosion and erosive wear. Caries Res. 2011; 45 Suppl 1: 60-68.

22. Sierpińska T, Stocka A, Gołębiewska M. Methods for measuring pathological tooth wear. Prosthodontics. 2010; 50(1): 4-9.

23. Berg-Beckhoff G, Kutschmann M, Bardehle D. Methological considerations concerning the development of oral dental erosion indexes: literature survey, validity and reliability. Clin Oral Investig. 2008; 12 Suppl. 1: S51-S58.

24. Ganss C. How valid are current diagnostic criteria for dental erosion? Clin Oral Investig. 2008; 12 Suppl.1: S41-S493.

25. Mulic A, Tveit AB, Wang NJ, Hove LH, Espelid I, Skaare AB. Reliability of two clinical scoring systems for dental erosive wear. Caries Res. 2010; 44(3): 294-299.

26. Dixon B, Sharif MO, Ahmed F, Smith AB, Seymour D, Brunton PA. Evaluation of the basic erosive wear examination (BEWE) for use in general dental practice. Br Dent J. 2012; 213(3): 128-129. doi:10.1038/ sj.bdj.2012.670

27. Carvalho TS, Colon P, Ganss C, Huysmans MC, Lussi A, Schlueter N, Schmalz G, Shellis PR, Björg Tveit A, Wiegand A. Consensus Report of the European Federation of Conservative Dentistry: Erosive tooth wear - diagnosis and management. Swiss Dent J. 2016; 126(4): 342-346.

28. Holbrook WP, Arnadóttir IB, Hlöðversson SO, Arnarsdóttir E, Jónsson SH, Sæmundsson SR. The Basic Erosive Wear Examination (BEWE) applied retrospectively to two studies. Clin Oral Investig. 2014; 18(6): $1625-1629$.

29. Bartlett DW, Lussi A, West NX, Bouchard P, Sanz M, Bourgeois S. Prevalence of tooth wear on buccal and lingual surfaces and possible risk factors in young European adults. J Dent. 2013; 41(11): 1007-1013.

30. Kaczmarek W. The state of mineralized dental tissues in young competitive swimmers. Ann Acad Med Stetin 2010; 56(3): 81-86.

31. Buchok RA, Belikov OB. Prevalence of noncarious lessions of the hard tissues of the teeth among students and cause-and-efect relationships of their onest. Buk. Med. Herald. 2012; 16(4): 26-30.

32. Strużycka I., Rusyan E., Bogusławska-Kapała A. Epidemiological study of prevalence and risk factors for dental erosions among Polish young adults. Pol Merkur Lekarski. 2016; 40(239): 308-313. 